\title{
Kollégák és növendékek szeretett mestere és társa: dr. Sallai Éva
}

\section{Schlichter-Takács Anett ${ }^{1}$ - Kolosai Nedda² - Fűzi Beatrix ${ }^{3}-$ Falus Iván ${ }^{4}$}

ª Magyar Agrár és Élettudományi Egyetem Kaposvári Campus, Neveléstudományi Intézetének egyetemi adjunktusa schlichter-takacs.anett@uni-mate.hu

${ }^{2}$ az Eötvös Loránd Tudományegyetem Tanító- és Óvóképző Karának egyetemi docense kolosai.nedda@tok.elte.hu

ª Budapesti Gazdasági Egyetem Kutatási Szolgáltató Központjának vezetője fuzi.beatrix@uni-bge.hu

${ }^{4}$ Eszterházy Károly Egyetem Egri Campus Pedagógiai Karának egyetemi tanára, professor emeritus

falusi@ektf.hu

ÜİTO volt. Elkötelezettsége, sokoldalú szakmai képzettsége, integratív pedagógiaipszichológiai szemlélete tette lehetővé, hogy a pályaszocializáció hangsúlyossá vált a pedagógusképzésben. Kezdeményezésére jött létre a Mentálhigiénés Hallgatói csoport az egyetemen. 2000-től kapcsolódott be a Magyar Videotréning Egyesület munkájába, majd elindította a módszer iskolai adaptációját Magyarországon.

PEDAGÓGUS volt (nagybetüvel). Emberi kapcsolatai nem korlátozódtak a szakmai támogatásra, a konzulensi teendők ellátására, a kollegiális együttlétre. Szakmaisága és elhivatottsága példaként szolgál kollégái és tanitványai számára, akik közül sokan MESTERüknek tekintették.

Kulcsszavak: Sallai Éva, nekrológ, emlékező sorok

DOI: 10.37205/TEL-hun.2020.1-2.05

„Ha őt hallgattad, újra hitet kaptál a munkádhoz...”

Sallai Éva 1976-ban a Bessenyei György Tanárképző Főiskolán orosz-pedagógia szakos általános iskolai tanári, majd 1981-ben az ELTE-n okleveles pedagógia szakos diplomát szerzett. PhD fokozatot 2003-ban a Debreceni Egyetem Neveléstudo- 
mányi Doktori Iskolában kapott. 1976-1988 között az Országos Oktatástechnikai Központban szerkesztőként és osztályvezetőként tevékenykedett. 1988-tól dolgozott a felsőoktatásban; 1988-90 között Szombathelyen a Berzsenyi Dániel Tanárképző Főiskola oktatója; 1992-2005 között a Színház- és Filmművészeti Egyetem óraadó egyetemi docense; 1990-2007 között a Pannon Egyetem egyetemi docense volt. 2005-től a Babeș-Bolyai Tudományegyetem Pszichológia és Neveléstudományi Karán vendégoktató. 2008-tól az Eszterházy Károly Fơiskola Neveléstudományi Tanszékének fóállású oktatója, majd 2010-2013 között tanszékvezető egyetemi docense, a tanárképzés intézményi felelőse.

ÚfíTÓ volt. Elkötelezettsége, sokoldalú szakmai képzettsége, integratív pedagógiai-pszichológiai szemlélete tette lehetővé, hogy a pályaszocializáció hangsúlyossá vált a pedagógusképzésben. Kitartó, áldozatos munkájának köszönhetően a pedagógus professziót jelentő érték- és kompetenciarendszer elsőként az országban a Veszprémi Egyetem tanárképzési programjába kerülhetett be. Ezt a koncepciót igazolta és erősítette meg a 111/1997-es Kormányrendelet a tanári képesítési követelményekről, és ez az elképzelés mind a mai napig érvényes. A lelki egészség védelmét szolgáló beállítódásának és közösségszervező munkájának gyümölcsét a hallgatók és az oktatók egyaránt élvezhették, mivel kezdeményezésére jött létre a Mentálhigiénés Hallgatói csoport az egyetemen. 2000-től kapcsolódott be a Magyar Videotréning Egyesület munkájába, 2008-tól volt az Egyesület szakmai vezetője. Dr. Sallai Éva indította el a módszer iskolai adaptációját Magyarországon, vezette az iskolai és a családi videotrénerek képzését. Szupervíziós támogatása mellett videotrénerek segítették a mindennapi gyakorlatban az osztálytermi interakció megértését és mélyítését, több tanítványa alkalmazta a módszert kezdő és gyakorlott pedagógusok készségfejlesztésére általános és középiskolákban, zenei képzésben, hátrányos helyzetű településeken müködő iskolákban országszerte.

2018-ig a Tanárképzők Szövetsége Mentor Szakosztályának elnöke volt. A pedagógusok támogatása iránti elkötelezettsége, tapintatos, erősségeket kereső hozzáállása és az emberi kapcsolatok fejlesztő erejébe vetett hite meghatározó a Szakosztály szellemiségében. Jelenlétével megalapozta a szakosztály közvetlen, szeretetteljes légkörét, aktív munkáját.

PEDAGÓGUS volt (nagybetűvel). Mindig eredeti és alkotó, inspiráló gondolatait írásos publikációin kívül, filmek, videofelvételek sora is őrzi. Mindemellett azonban Éva hagyatékának jelentős részét a környezetében élő emberek szellemi fejlő- 
dése, lelkületének alakulása, emberi lényegének bontakozása is jelzi. Emberi kapcsolatai nem korlátozódtak a szakmai támogatásra, a konzulensi teendők ellátására, a kollegiális együttlétre. Szinte hihetetlen, hogy milyen mértékben tudott azonosulni hallgatóival, munkatársaival. Számára mindenki sokrétủ emberi dimenzióban volt jelen. Átsegített mindenkit az idősödő szülők támogatásának nehézségein, esetleg elvesztésén, párkapcsolatának válságán vagy csak a mindennapok nehézségein. Szakmaisága és elhivatottsága példaként szolgál kollégái és tanítványai számára, akik közül sokan MESTERüknek tekintették.

Halálakor sokunkban maradt a befejezetlenség érzése, felgyülemlett bennünk a ki nem mondott szavak özöne, a köszönet kifejezésének ellehetetlenülése. Éva, megdöbbentő űrt hagytál magad után!

\section{Sallai Évára tanítványai és kollégái segítségével emlékezünk}

Éva, nyomot hagytál az életünkben: melletted elkerülhetetlenül gyarapodtunk emberileg és szakmailag. „Az életet hosszában kell nézni.” - szoktad mondani, s ez igaz most is, amikor Téged gyászolunk: a mérhetetlen fájdalom mellett így könynyebb örülni annak, amit adtál, hagytál nekünk.

A tökéletesen időzített pillanatokban kimondott frappáns szállóigéid a lehető legjobban ragadták meg a lényeget, humorosak, ütősek és emlékezetesek voltak, s közelebb vittek egy helyzet, mások, és miért ne, önmagunk megértéséhez. Nem csak tanítottad a rogersi szemléletet, te azonosultál vele, s kiváltságosnak érezhettük magunkat mindannyian, akik leülhettünk veled, ember az emberrel, beszélgetni. Ezek a „találkozások”, összekapcsolódások pótolhatatlan űrt hagynak, s a vágyat, hogy mi magunk létrehozhassuk az élményt, amit tóled kaptunk, s amit te is oly nagyra értékeltél.

Azon kevesek közé tartoztál, akiknek nemcsak a tervezés, hanem a megvalósítás is erőssége: jól felépített koncepcióba megfontoltan illesztetted az ízlésesen kidolgozott részleteket. Így építetted fel a tananyagot és az óráidat, amelyeken semmi sem történt céltalanul, mindennek megvolt a helye. Szakmai elkötelezettséget kértél, de tudtad, hogy csak akkor állhat teljesen össze a kép, ha merünk önmagunkkal szembenézni. És ha mertünk, rendkívül sokat nyertünk. Így vezettél be bennünket a videotréning, a társas interakciók mikroelemzésének világába, s tanítottál meg arra, hogy a lényeg az apró részletekben rejlik. Hihetetlen türelemmel 
elemezted és elemeztetted másodpercről másodpercre a legapróbb gesztusokat, s tanítottál meg arra, hogy ilyen apró elemekből lehet újraépíteni fájó szülő-gyerek kapcsolatokat, sikertelen osztálytermi kölcsönhatásokat.

Így álmodtad meg és hoztad létre az otthonoddá váló házat és kertet is, [...] ahogy te emlegetted: azt a másik bolygót, ahová kilőtted magad töltekezni, [...] hogy aztán bennünket villanyozzál fel jelenléteddel.

Szakértelmeddel, elhivatottságoddal, életszemléleteddel, humoroddal formáltad kolozsvári közösségünket: kollégákat és diákokat. Igy emlékszünk Rád: munkába merülten, kamerát szorongatva, s néha - a színfalak közt - dalra fakadva, táncra perdülve, kacagva és kacagtatva.

Hálás vagyok, hogy tisztelhettelek és szerethettelek tanáromként, kollégámként, mentoromként és főleg barátomként. Emléked kitörölhetetlen.

(Dr. Kotta Ibolya adjunktus, Babeș-Bolyai Tudományegyetem, Kolozsvár)

[...] Sallai Éva pedagógusi munkáján keresztül, tanulói szerepben megtapasztalhattam azt, hogy a mai kor kiváló pedagógusa biztos alapokra épített szakmai tudással bír, mindig nyitott az új ismeretek megszerzésére, és erre sarkallja diákjait. Nem irányítja diákjait, hanem felajánlja a választás lehetőségét, miközben a döntéssel járó következmények és felelősségvállalás fontosságát is megvilágítja, és a feltétel nélküli elfogadás érzését sugallva mer olyan közelséget vállalni diákjaival, mely egyszerre áraszt szeretetet, biztonságot, bátorítást, és kölcsönös tiszteletet feltételez mindkét fél részéről.

Sallai Éva a szakmai ismereteken túl megtanított arra is, hogy milyen pedagógusi és emberi értékeket kell képviselnem hivatásom gyakorlása során, és véleményem szerint ez a legtöbb, amit egy pedagógus diákjának adhat.

Azt gondolom, ahhoz, hogy pedagógusi munkánk során követendő példák lehessünk, szükségünk van pedagógusi példaképre, és szerencsésnek érzem magam, hogy nekem megadatott, hogy követendő példaképre találjak Sallai Éva személyében.

Példaképem Ő, akit egész életemen át magamban hordozok, és bízom abban, hogy pedagógusi mintáját hozzá méltó és emlékéhez illő módon nevelőként hűen tudom képviselni. Hálás vagyok azért, hogy ismerhettem, diákja lehettem, köszönettel tartozom mindazért, amit szakmai és emberi szinten tőle kaptam. Példaképemként tovább él bennem Sallai Éva - A PEDAGÓGUS. 
(Kardos Melinda)

Szerencsés ember az, akinek megadatik, hogy MESTERT kap az élettől. Egy mestert, aki szakmailag és emberileg olyan világos, értékes és tiszta világot képvisel, amelyre ebben a zavaros világban sokan csak vágyakoznak. Éva tanárnő, te ilyen mester voltál számomra.

Amikor sok évvel ezelőtt megtudtam, hogy veled dolgozhatok, még nem is sejtettem, hogy a veled való kapcsolat micsoda gazdagodást és gyarapodást hoz majd számomra. Ma már tudom, tanárom voltál, mesterem lettél.

Szerettem Hozzád járni Almádiba. Nehéz szavakba önteni, milyen érzés volt részesülni abból a különleges világból, amit a férjeddel a hegyoldalban teremtettetek. Amikor találkozót kértem, minden egyes alkalommal szigorú önkorlátozással indultam Almádi felé. Kértem pár órát, hogy segítséget, útmutatást kaphassak a munkámhoz, de ezek az órák valahogy mindig megsokszorozódtak. Órákat kértem, de tőled mindig napokat kaptam. Ezek a találkozások mindig azzal kezdődtek, hogy „Hogy vagy, Andikám?”. Szerettem, amikor megkérdezted, mert tudtam, ami nekem nehéz, az máris súlytalanná válik, amint megosztom Veled, mert Tőled tanultam: „Helyzet van, nem probléma.” - amit meg lehet oldani. És már azt is tudom, hogy „egy felnőtt ember mindent meg tud oldani”. Szeretet, törődés és aggódás volt a hangodban, s legfóképp a szemedben. Szerettem a nyugalmadat, a végtelen türelmedet. Néha, amikor nehéz volt az élet, tartottad bennem a lelket. Perceken át hallgattál, aztán megkérdezted: „Kérdezhetek?”, s olyan tiszta és logikus kérdésekkel kapcsoltad be a reflektorokat körülöttem, hogy titkon elkapott a szégyenérzet, hogy vajon magamtól miért nem láttam meg ezt a tisztaságot. Ha valami nem volt a legjobb, te egyszer sem mondtad azt, hogy ez nem jó. Újragondolásra, továbbgondolkodásra tanítottál.

Amikor utoljára láttalak, olyan szép voltál. Más, mégis olyan szép. A mosolyod, a hangod és a figyelmességed, a derü, miközben neked volt erre a legnagyobb szükséged. Benned mindig volt erő és kíváncsiság irántam, irántunk. Csodáltalak. Hogy lehet ezt a helyzetet ilyen méltósággal és alázattal viselni?

Amikor utoljára hallottam a hangod, derüs voltál. Megbeszéltük, hogy annyi szépség van még az életben. A feladatokat meg lehet és meg is kell valósítani, de az igazán fontos dolgok nem mindig a feladatokhoz kötődnek. Örültél az örömömnek, akár szakmai, akár magánéleti történésekről volt szó. Biztattál a „munka 
és magán-örömök egyensúlyának megteremtésére”, „drukkolok neked” - írtad egy leveledben, mint a gyermekéért aggódó édesanya.

Szakmailag nagyra becsültelek, emberileg csodáltalak. Tisztelet és szeretet, hitelesség és következetesség, elveszve a szavakban, elmerülve az érzésekben, nehéz elhinni, hogy már másutt vagy. Minden leveledet így zártad: „Szeretettel ölellek”. Tanárnő, szeretettel és tisztelettel hordozom tovább az emlékedet, mert szomorú ember az, akitől az élet elveszi a mesterét.

(Ritter Andrea)

Meghallottam a szomorú hírt, s hirtelen megjelent egy éles kép a szemem előtt, ahogyan együtt vagyunk (dolgozunk, beszélgetünk) a tanszéki irodánkban, ahol egy évtizednél is több időt töltöttünk együtt. Csak ritkán ketten, hiszen közvetlenséged és segítőkészséged rengeteg hallgatót bátorított arra, hogy keressenek. Fülembe csengenek mondataid, mindig élveztem, amiről és ahogyan beszélsz. Széleskörű, hihetetlenül alapos szakmai tudásod, elszánt tenni akarásod a pedagógus mesterség professzionális szintre emeléséért, a személyközpontú nevelésért, a kapcsolati kultúrába vetett hited és az a hitelesség, ahogyan ezt gyakoroltad minden nap varázslatos volt számomra. A derủ és az optimizmus élt velünk csöppnyi szobánkban általad. Évi, átkeltél valahová, legyen békességed, de nem hal meg az, aki szívekben él tovább! Bennem is. 


\section{Dr. Éva Sallai: The Beloved Master and Colleague}

She was an INNOVATOR. Her commitment, multi-faceted professional training, and integrative pedagogical-psychological approach made possible the socialization of our career to come to the fore in teacher education. On her initiative, the Student Group on Mental Health was established at the university. She joined the Hungarian Video Training Association in 2000, subsequently adapting the technique in Hungarian schools.

She was a TEACHER (in block capitals). Her relationships were not limited to professional support, advisory duties, and collegiality. Her professionalism and dedication set an example for her colleagues and students, many of whom considered her their GURU.

Keywords: Éva Sallai, necrology, lines 